\title{
黄砂の健康影響一疫学文献レビュー
}

\author{
橋爪 真弘 ${ }^{* 1}$, 上田 佳代 ${ }^{* 2}$, 西脇 祐司 ${ }^{* 3}$, 道川 武紘 ${ }^{* 3}$, 小野塚大介 ${ }^{* 4}$ \\ ${ }^{* 1}$ 長崎大学熱帯医学研究所国際保健学分野 \\ *2 国立環境研究所環境健康研究領域環境疫学研究室 \\ *3 慶應義塾大学医学部衛生学公衆衛生学 \\ *4 福岡県保健環境研究所企画情報管理課
}

\section{Health Effects of Asian Dust Events: A Review of the Literature}

\author{
Masahiro HASHIZUME* ${ }^{* 1}$, Kayo UEDA ${ }^{* 2}$, Yuji NISHIWAKI ${ }^{* 3}$, Takehiro MICHIKAWA ${ }^{* 3}$ \\ and Daisuke ONOZUKA ${ }^{* 4}$ \\ ${ }^{*}$ Institute of Tropical Medicine, Nagasaki University \\ ${ }^{*}$ National Institute for Environmental Studies \\ ${ }^{*}$ Department of Preventive Medicine and Public Health, School of Medicine, Keio University \\ ${ }^{*}$ Fukuoka Institute of Health and Environmental Sciences
}

\begin{abstract}
Asian dust, called 'kosa' in Japan, is the long-range transport of atmospheric pollutants originating from the desert areas of China and Mongolia. Although Asian dust has a long history of appearing in Japan, it is only quite recently that there is increasing concern for its possible adverse health effects. We reviewed the epidemiologic evidence of potential health effects of Asian dust events. PubMed was used to search for the following keywords: Asian dust, yellow sand, desert dust, dust storm, sandstorm, mortality, death, morbidity, hospitalization, hospital admission, health, pulmonary and respiratory. The search was limited to the epidemiologic studies published between January 1980 and May 2009. JMEDPlus was used to search for Japanese literature. Seventeen studies were retrieved from PubMed and one study from JMEDPlus. In addition, one study was identified for reviewing from the references of another study. In total, we identified 19 epidemiologic studies (3 for mortality, 13 for hospital visits or admissions and 3 for respiratory functions or symptoms) mainly from Taiwan and Korea. There were many combinations of outcomes and lagged exposures examined, and some suggested possible associations of dust exposure with an increase in mortality and hospital visits and admissions due to cardiovascular and respiratory diseases, whereas the rest of the studies did not show statistically significant associations. The evidence from these studies was limited because exposure assessments were inadequately described and potential confounders were insufficiently controlled. Well-designed epidemiological studies are required to clarify any potential health effects of Asian dust events in Japan.
\end{abstract}

Key words: Asian dust (黄砂), yellow sand (黄砂), sandstorm（砂嵐）, literature review（文献レビュー), epidemiology (疫学), health effect (健康影響)

はじめに

黄砂は中国大陸内陸部の砂漠で風によって上空に巻き 上げられた土畩・鉱物粒子が東アジアなどの広範囲に飛

受付 2009 年 7 月 21 日, 受理 2009 年 12 月 2 日

Reprint requests to: Masahiro HASHIZUME

Department of International Health, Institute of Tropical Medicine, Nagasaki University, 1-12-4 Sakamoto, Nagasaki 852-8523, Japan TEL/FAX: +81(95)819-7808

E-mail: hashizum@nagasaki-u.ac.jp
来し，大気中に浮遊あるいは降下する現象である。黄河 流域や中国大陸内陸部の砂漠で近年急速に広がる過放牧 や耕地拡大が原因の一つとされ, 砂漠化・森林伐採・土 壤劣化などの人為的影響による環境問題としての認識が 高まっている（1）。土壌由来の黄砂粒子は粒径が数 $\mu \mathrm{m}$ か ら数十 $\mu \mathrm{m}$ と粗大で, 化石燃料の燃焼などによる人工発 生源に由来する粒径 $2.5 \mu \mathrm{m}$ 以下の微小粒子に比べると, 呼吸器系への影響が小さいと考兄られてきた。しかし, 最近の研究では黄砂ダストに硫酸塩や硝酸塩が多く含ま れることが明らかとなり（2）これらは主に中国東部工 
業地带で排出される大気污染物質が酸化し二次的に発生 すると推測されている。一方，台湾に抢ける調査では， 黄砂日の大気中菌類胞子数は非黄砂日に比べて増加して いることが観察されている(3)。また, 黄砂発生源表層 土壤から採取したダストには，真菌など微生物が付着し て扔り，動物実験により吸入するとアレルギー反応を誘 発し, 気道の炎症を起こすことが示唆されている(4)。以 上のような知見を踏まえ, 黄砂降下地域である日本に招 いても黄砂の健康影響について懸念が高まっており, 今 後この問題に関する研究が重要になると考兄られる。筆 者らは, 黄砂の七トへの健康影響に関するこれまでの知 見を明らかにする目的で, 疫学文献のレビューを行った。

\section{方法}

関連論文の検索は, PubMedを用いて 1980 年 1 月 1 日〜 2009 年 5 月 31 日の間に公表されている論文について 行った。検索は，黄砂および砂漠由来の砂塵を定義する ことばとして "Asian dust”, “yellow sand”, “desert dust", “dust storm”, “sandstorm”，アウトカムを示す用語として "mortality", "death", "morbidity", "hospitalization", "hospital admission”, "health”, “pulmonary”, “respiratory”党組及合 わせて行った。上記キーワードにより検索された 45 件の 論文のうち，抄録や本文を参考に，総説・論説・コメン ト・症例報告 $(7$ 件), 胸部 X 線等の画像所見を示寸形容 詞として“sandstorm”が用いられた臨床研究 (5 件), 発 生源が中国大陸内陸部以外の砂漠（サ八ラ砂漠など）由 来の砂塵の健康影響についての検討 (3 件), 砂塵内に含 まれる微生物や胞子ついての検討 (3 件), 七下細胞に対 する実験的検討 (3 件), 気象・環境全般について (2 件), 粒子の特性に関する検討 (2 件), 黄砂に対する認識調查 （1 件），黄砂に上る大気污染物質の効果修飾を検討した 研究 (1 件), 診断に関する検討 (1 件) を除くと, 該当 論文は 17 件（死亡 3 件, 入院・受診 12 件, 症状増悪・ 機能変化 2 件）であった。さらに, 総説の参照文献より 入院に関する論文が新たに 1 件加わった (5)。

日本語の文献検索はJDream II (http://pr.jst.go.jp/jdream2/) で提供されているJMEDPlusを用いた。最終の検索は 2009 年 11 月 10 日に行った。同データベースでは 1981 年 〜 2009年までの文献を含む。曝露を示す検索用語として “黄砂”を，健康影響を示す用語としては “健康”，“疫 学”, “死亡”, “入院”, “救急”, “受診”, “外来”, “呼吸 器”, “循環器”, “疾患”, “喘息”, “アレルギー”, “鼻炎”, “花粉症”, “結膜炎”, “症状”, “喘鳴”, “息切孔”を用 い, 84 文献が検索された。そのらち, Limitオプション を用いてヒトを対象とする原著論文の夕に限定したと ころ，8文献が該当した。抄録の内容より，黄砂以外の 環境因子 (大気污染物質, 生活環境, 気象) の健康影響 について検討（3 件), 粒子状物質濃度についての検討 (2 件), 花粉測定についての検討（2 件）を除くと該当す る論文は 1 件のみであった。
最終的に 19 件（死亡に関するもの 3 件，入院・受診 13 件, 症状増悪・機能変化 3 件）の文献をレビュ一の対象 とした。これらの対象論文より, 研究の実施された地域, 曝露評価，研究デザインおよび解析方法，アウトカムに 関する情報について抽出した。

\section{結果}

\section{研究地域}

研究対象地域は, 台湾 12 件 (6-17), 韓国 4 件 (18-21), 中国 1 件 (5)，日本 1 件 (22)，カナダ 1 件 (23) であった。 カナダからの報告は, 1998 年春にゴビ砂漠で発生し北米 西海岸飞到達した黄砂イベント（24）時の健康影響につ いて検討したものである。

\section{曝露評価}

黄砂曝露の定義として最も多かったのは粒子状物質 (Particulate matter:PM) 濃度が一定の值以上とするもの であった (6, 8-17)。台北に抢ける研究では粒径 $10 \mu \mathrm{m}$ 以 下の粒子状物質（ $\mathrm{PM}_{10}$ ) の日平均濃度が $115 \mu \mathrm{g} / \mathrm{m}^{3}$ 以上 を黄砂と定義したり (6)，人為由来大気污染物質が少な いとされる郊外での日平均 $\mathrm{PM}_{10}$ 濃度が $100 \mu \mathrm{g} / \mathrm{m}^{3}$ (6) ま たは 1 時間值が $125 \mu \mathrm{g} / \mathrm{m}^{3}$ 以上が 3 時間以上持続した場 合 $(8,10,12,14,15,17,25)$ と定義する研究もあった。 粒径 $2.5 \mu \mathrm{m}$ 以上 $10 \mu \mathrm{m}$ 以下の粒子状物質 $\left(\mathrm{PM}_{10-2.5}\right)$ や $\mathrm{PM}_{10} /$ 粒径 $2.5 \mu \mathrm{m}$ 以下の粒子状物質 $\left(\mathrm{PM}_{2.5}\right)$ などの指標 を用いた報告もあった（6）。Chen ら（9）の報告では， $\mathrm{PM}_{10}$ 濃度が急上昇した場合を黄砂イベントと定義したが, カットオフ值の記載がなかった。PM 濃度と後方流跡線 解析を併用している検討 (7) も久られた。各国気象庁に より報告された黄砂イベントを用いた報告は日本 (22), 韓国 (21) からそれぞれ 1 件ずつあり，いずれ子気象庁に よる黄砂の定義についての記載はなかった。カナダから の報告 (23) では, 衛星りモートセンシングや地表観測に よる詳細な黄砂イベントの報告 (24)をもとにしている。 一方, 黄砂イベントの日付のみの記載 $(18,19)$ や, 曝露 定義についての記載がみられないもの $(5,20)$ もあった。

\section{研究デザイン・解析方法}

19 文献のらち，黄砂日と非黄砂日とでアウトカム（死 亡・入院・受診) 発生数の比較を行ったデザインは 14 件 （7-18, 21, 23), 時系列解析を用いたものは 4 件 $(5,6$, 19,20)であった。小沢ら（22）は，春季カタル増悪日と 黄砂観測日との関連を検討しているが，統計学的検定を 行っていない。交絡因子となり光る気象因子の調整がな されたものは 12 件 (5, 6, 8, 10-12,14-19) であり, 打子に 気温と湿度について調整がなされている。共存污染物質 については 9 文献で記載されて和り，いずれも $\mathrm{PM}_{10}$ と才 ゾンについて調整されていた（8，10-12，14-18）。 


\section{アウトカム}

死亡をアウトカムとした疫学研究は 3 件であった。ソ ウル（韓国）に打忷る研究が 2 件 $(18,19)$, 台北（台湾） に扔ける研究が 1 件 (9) であった。Chen ら (9) は台北に 沶いて黄砂日 1 日後の呼吸器疾患死亡が $8.3 \%, 2$ 日後の 総死亡 $5.2 \%, 2$ 日後の循環器疾患死亡が 2. $7 \%$ 増加した と報告した。ただし，いずれる統計学的に有意でない。 交絡因子となり光る大気污染物質や気象因子の調整がな されているかの記載はない。また, 黄砂日の日付の記載 はあるものの黄砂の定義は明確でない $\left(\mathrm{PM}_{10}\right.$ カットオフ 值が不明)。Kwonら (19) は, Poisson generalized additive model を用いて, 台北に抢战る黄砂日 2 日後の事故死を除 く総死亡（全年齢）が 3.4\%（95\%信頼区間-0.5，7.4）, 同総死亡（65 歳以上） $5.3 \%$ (95\%信頼区間 0.3，10.5), 心血管・呼吸器疾患死亡が 2. 1\%（95\%信頼区間 -4.2 , 8.8）増加したと報告した。しかし, 黄砂日の日付の記載 はあるものの黄砂の定義は記述されていない。また共存 大気污染物質の調整に関する記載はない。Hwang ら (18) の報告では, ソウルに拈いて 2002 年 3 月 21 日と 4 月 8 日 に起きた黄砂の前後 14 日を黄砂日とし，これらの日は 対照日に比べて全死亡が 2. 5\%（95\%信頼区間-5.0, 10.6）増加し，呼吸器疾患死亡が $36.5 \%$ （95\%信頼区間 0.7，85.0)，65 歳以上の死亡が $2.2 \%$ (95\%信頼区間 $-7.4,12.8)$ 増加した。前出の文献同様, 黄砂日の日付 の記載はあるものの研究に用いた黄砂の定義は明確で ない。また，タイムラグによる影響の差は検討されてい ない。

黄砂が疾患の発症や増悪に伴ら入院・受診に与える影 響について検討した疫学研究は 13 件であった。循環器疾 患（心血管疾患，脳血管疾患）について 7 件 $(5-7,10$, $15,16,23)$, 呼吸器疾患坾て 8 件 (5-7, 11-13, 17, 23), その他, 結膜炎 (14), アレルギー性鼻炎 (8) が各 1 件ず つであった。

呼吸器疾患との関連については, 台北, 中国, カナダ に沶いて検討されている。台北における研究では, Cheng ら（11）が黄砂発生翌日の肺炎に上る入院が, 非黄砂日に 比較して 4.9\%（95\%信頼区間 0.2，9.8）増えることを 示した。また, Chan ら (7) は慢性閉塞性肺疾患による救 急受診が非黄砂日に比べて 20\%（0.9人（95\%信頼区間 $0.1 ， 1.7) ）$ 増加したことを報告した。一方，台北で行わ れた他の報告では, 黄砂日から数日後の間に呼吸器疾患 (13), 喘息 (17), 慢性閉塞性肺疾患（12）飞上る入院数 は増えていたものの，いずれも統計学的に有意な結果で はなかった。Mengら（5）による民勤（中国）での検討で は, 呼吸器疾患による入院リスクの有意な増加を黄砂発 生 3 日後に認めた（男性：14\%（95\%信頼区間 1，29）， 女性：18\%（95\%信頼区間 0，41））。 日後の上気道感染 および 6 日後の肺炎による入院増加は男性にの及認めら れ，それ杂 28\%（95\%信頼区間4，59），17\%（95\%信

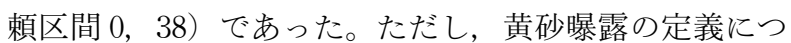
いて記載はなかった。カナダにおお検討では，黄砂イ

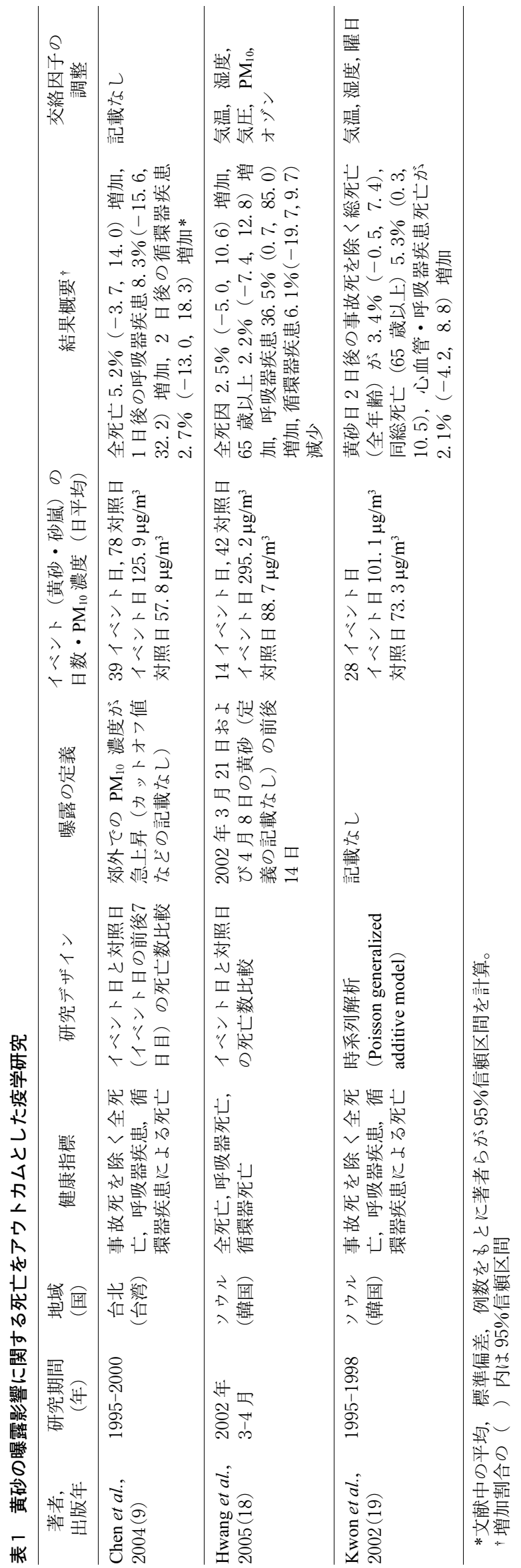




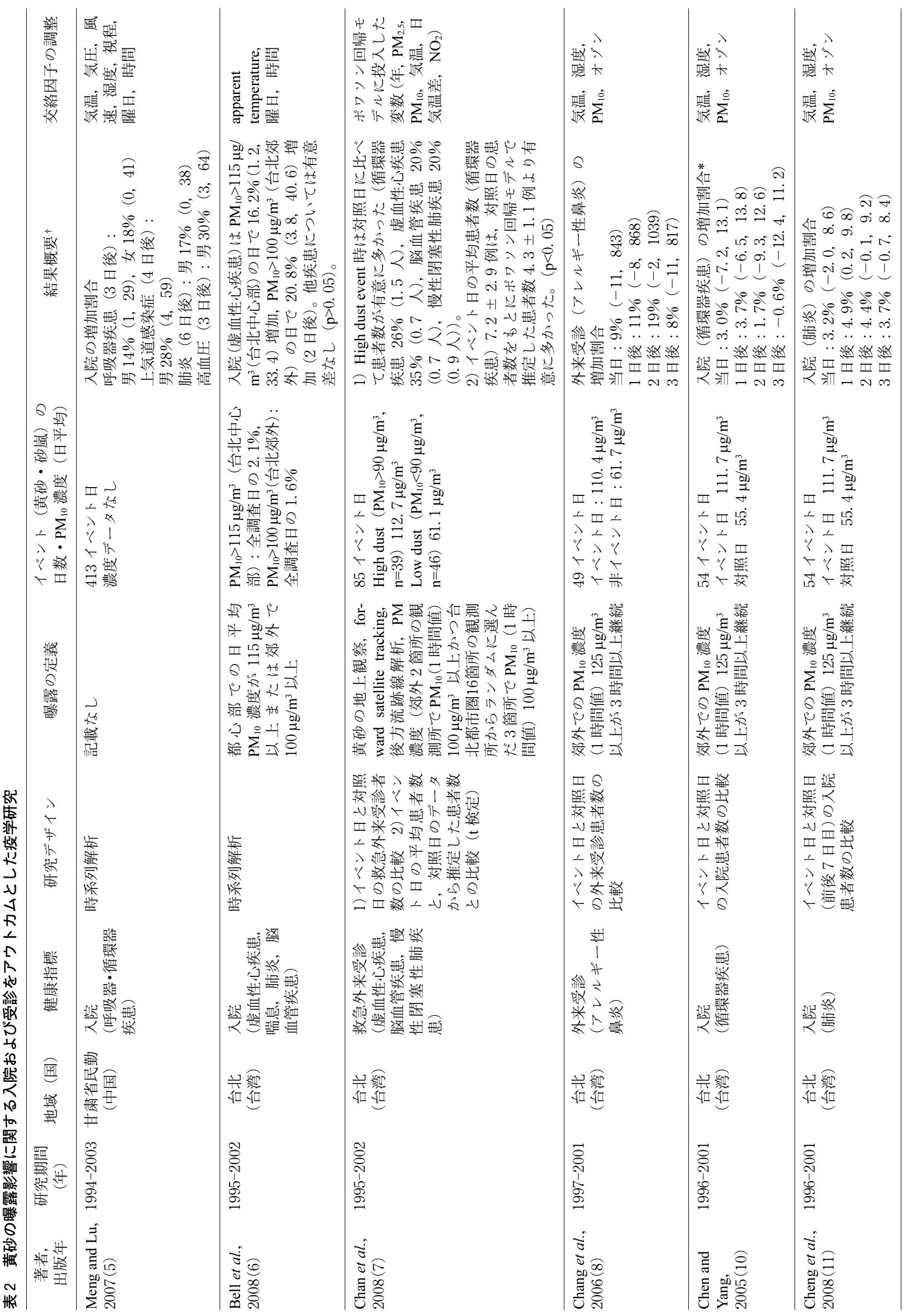




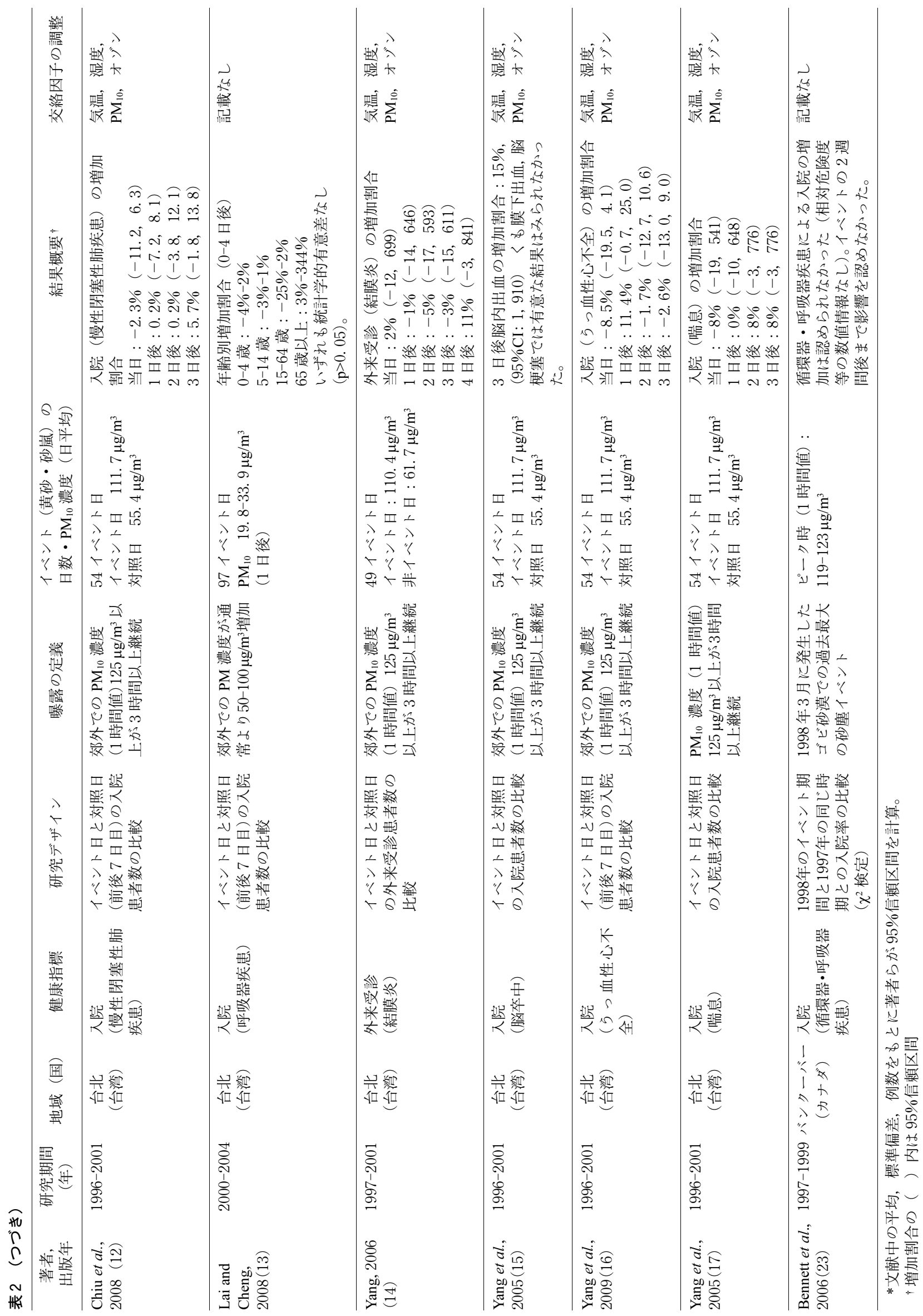




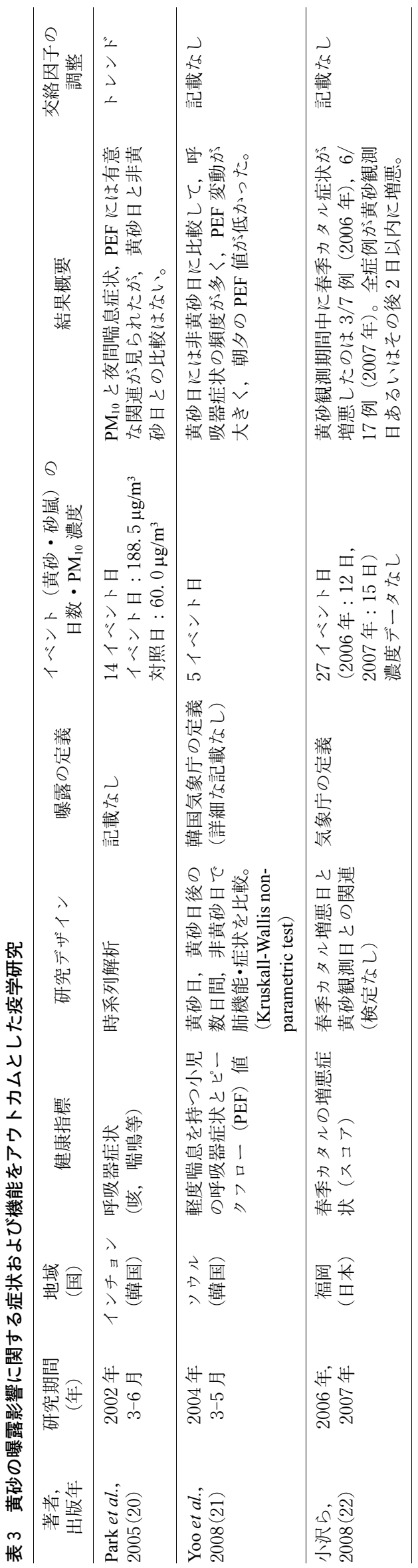

ベント後には呼吸器疾患による入院や受診患者数の増加 はみられなかった（23）。

循環器疾患との関連では, 台北での検討では, 黄砂日 と非黄砂日との比較で心血管疾患による入院・受診の有 意な増加はみら秃なかった $(7,10,16)$ 。乙かし, Chan ら （7）の報告では，24 時間平均 $\mathrm{PM}_{10}$ 濃度が $90 \mu \mathrm{g} / \mathrm{m}^{3}$ を超光 る黄砂日は, 非黄砂日に比較して, 脳血管疾患による救 急受診が 20\%（0.7人（95\%信頼区間 $0.1 ， 1.3 ）$ ) 増加 した。また 24 時間平均 $\mathrm{PM}_{10}$ 濃度が $90 \mu \mathrm{g} / \mathrm{m}^{3}$ 以上の黄砂 日打打る虚血性心疾患, 脳血管疾患, 慢性閉塞性肺疾 患による総受診者数 $(7.2 \pm 2.9$ 人) は対照日の患者数か ら推定した受診者数（4.3 1.1 人）と比較して有意に上 昇していた。また，民勤（中国）に打涂討では，黄 砂イベント 3 日後に高血压による入院リスクが男性で 30 \%（95\%信頼区間 3，64）増加した（5）。カナダにおける 検討では, 統計学的に循環器疾患に上る入院患者数の有 意な増加は認められなかった (23)。Yangら（15）は，脳 血管疾患を層別化したところ, 脳出血による入院が黄砂 イベント 3 日後に統計学的に有意な增加を認めた $(15 \%$, 95\%信頼区間 1，10)。一方，Bellら（6）の検討では，脳 血管疾患との明らかな関連を認めなかった。黄砂日と対 照日でアレルギー性鼻炎による受診者数を比較した台北 での研究 (8) では, 黄砂日の 2 日後に $19 \%$ の増加がみら れたものの統計学的には有意ではなかった。結膜炎につ いても検討されているが，明かな関連は認められなかっ た (14)。

黄砂による症状・機能の変化を検討した研究は 3 件で, 研究地域はソウル（韓国）（21），インチョン（韓国）(20), 福岡 (22) であった。Yooら (21) は，気管支喘息の小児 を対象とした検討で, 黄砂日は非黄砂日に比べて呼吸器 症状の頻度が増加し, 最大呼気流量（PEF）の低下やそ の変動の増加が認められたと報告した。一方，Park ら （20）は，気管支喘息と診断された患者について，黄砂飛 来時期の大気污染物質濃度と症状の増悪やPEF につい て検討している。一般化推定方程式（GEE）を用いた解 析では, $\mathrm{PM}_{10}$ 濃度の増加はPEF 変動や夜間の症状増悪に 関連しており, 黄砂イベントが呼吸器症状に影響を与兄 ている可能性を示唆した。小沢ら（22）は重症のアレル ギー性結膜炎である春季カタル患者 20 人を対象として 臨床症状の増悪日と黄砂観測日の関連を検討し, 増覀症 例の 40\%が黄砂観測時期にみられたことを報告した。し かしいずれの研究も交絡因子となり得る共存大気污染物 質や気象因子の調整がなされていなかった。また統計学 的検定がなされていない (22), 黄砂曝露の定義の記載が ない(20)などェビデンスのレベルは十分とは言えな かった。

\section{考察}

黄砂曝露の健康影響に関する疫学研究は主に台湾, 韓 国など近隣諸国の都市に执ける報告が多く，黄砂日と対 
照日の死亡者・患者数を比較するデザインや時系列解析 など短期影響の報告が目立った。いくつかの文献に扣い ては黄砂の飛来日もしくは数日後に呼吸器疾患および 循環器疾患による死亡または受診・入院の増加との関連 があったが，統計学的有意差のみられない文献も多数 あった。わが国に拈いては 1 件の疫学文献が報告されて いたが，交絡因子の調整がなくエビデンスのレベルは十 分とは言えない。いずれの研究も黄砂曝露指標や調整す べき交絡因子が統一されて抢らず，地域間比較は困難で あった。

多くの研究で, 黄砂の曝露指標として $\mathrm{PM}_{10}$ が用いられ ていた。しかし， $\mathrm{PM}_{10}$ は黄砂由来の粒子だけでなく，当 該地域の大気污染物質由来の粒子も含几で打り，これら の指標を黄砂の曝露指標として用いることの妥当性に関 しては十分に検討されておらず，今後の課題である。一 方，多くの文献で曝露（黄砂日）の定義が明確に述べら れて抢らず $(5,9,13,19-22)$, 黄砂曝露の妥当性について 十分に評価することが困難であった。黄砂による健康影 響の量一反応関係を検討するために，単に黄砂日と非黄 砂日との比較だけでなく, 黄砂の濃度を考慮した曝露評 価を行らことも検討されるべきである。我が国の黄砂飛 来の判定は視程距離を基準としているが，今後わが国に 扣いて黄砂の疫学研究を実施する際は, 曝露評価指標の 十分な検討が必要である。特に黄砂と対象都市に打ける 大気污染物質由来の粒子とは，その健康影響が異なる可 能性があり，その区別が重要であろう。環境省や国立環 境研究所が設置するライダー（レーザーレーダー）は非 球形の黄砂エアロゾルと球形の大気污染エアロゾルを分 離して高度分布を測定することができ (26), 黄砂の曝露 指標として有用な可能性があり検討すべきと考兄る。疫 学研究への応用にあたり特に留意すべき点は，1）ライ ダーは地上 120-150 $\mathrm{m}$ 以上の上空に拈ける黄砂の分布を 捉えることに優れているが, 疫学研究における曝露指標 として適切と考えられるのは, ヒトが吸入する地上付近 の黄砂濃度である。ライダーで測定された上空の黄砂分 布から地上付近の黄砂曝露を推定することが可能かどう かの検討が必要であろう。2）ライダーで測定されるのは 黄砂の重量濃度ではなく, 上空に向けて射出したレー ザー光がエアロゾルで散乱された光の単位距離あたりの 減衰量 (消散係数) である。消散係数と粒子の重量濃度 や粒径との関係について検討する必要があろう。ライ ダーの詳細については，国立環境研究所ライダーホーム ページが有用である（http://www-lidar.nies.go.jp）。

多くの文献で交絡因子やバイアスの影響が十分に考慮 されているとは言えず，これらの研究では十分なエビデ ンスが提示されているとは言いがたい。一般に大気污染 の時系列解析やケースクロスオーバ一解析に打ける交絡 因子として重要なものは, (1)気温や湿度などの気象因子, (2)共存大気污染物質 $\left(\mathrm{NO}_{\mathrm{x}}, \mathrm{O}_{3}, \mathrm{SO}_{\mathrm{x}}\right.$ 等) (3)季節変動や トレンド，曜日などである $(27,28)$ 。時間依存的に変化 する上記因子は交絡因子となりえるのに対し，短期間で
時間とともに変化しない属性，例えば性，年齢，喫煙習 慣などはこれらの解析で曝露の短期影響を見る場合，交 絡因子として考慮する必要がない。多くの文献で用いら れていた黄砂日と対照日の死亡拈よび患者数を比較する デザインでは，上記(1)(2)の調整に関して十分記述されて おらず，よってこれらの因子が適切に調整されているか の判断は困難であった。(3)にいては, 曝露も交絡因子 も短期間で系統的に変化していないと仮定すれば，対照 日を 1 週間前と後の同じ曜日にとることで調整がなさ れていると考えられるが，十分なエビデンスを得るため には，時系列解析やケースクロスオーバ一解析におい てこれら交絡因子を適切に調整する必要がある。また, 疫学研究に打けるバイアスの原因として測定誤差 (measurement error) を常に考慮する必要がある。大気污 染の疫学研究に扣いては測定誤差の影響について理論的 な検討がなされてきた (29)。測定䛊差のらち最も大きな 問題と考えられるのが曝露に関わる測定誤差である。な かでも，曝露指標として特定の観測所で測定された大気 污染物質濃度を集団代表值として用いる場合，個人レ心゙ ルの曝露との䛊差が問題と考兄られる。黄砂の疫学研究 に打いてもこの問題が生ずるため, 結果の解釈に注意を 要することは他の大気污染疫学研究と同様である。また, 有意な差が見られなかった文献が多かったが，一般に通 常の大気污染疫学研究に比べて黄砂イベントが年間を通 じて限られた時期にしか観測されないため，十分なサン プルサイズを得るためのより慎重な検討が必要と考えら れる。

近隣諸国に打ける疫学研究の結果がわが国に打いても 当てはまるとは限らない。日本に到達する黄砂の粒径分 布は直径 $4 \mu \mathrm{m}$ 付近にピークがあるが, 北京では粒径分布 は直径 4.7-7.0 $\mu \mathrm{m}$ 付近にピークがあることがわかって いる (2)。一般に粒子径が小さい注ど気道下部に到達し やすいとされ, 直径 $3 \mu \mathrm{m}$ 以下の粒子は下気道まで達し, 直径 $1 \mu \mathrm{m}$ 以下では肺胞に到達するとされる (30)。黄砂 の粒径分布の違いによって健康影響が異なる可能性は否 定できない。また，日本上空で採取した黄砂は黄砂発生 源近くで採取した黄砂に比べ，土壤起源でないと考えら れる硫酸イオン，硝酸イオン，アンモニウムイオンなど が検出され，中国大陸沿岸部の産業地帯上空を通過する 過程でこれら化学物質が黄砂粒子に付着する可能性が指 摘されている (31)。黄砂粒子の化学的組成の違いによる 健康影響についても検討が必要であろう。さらには，共 存大気污染物質濃度や気象因子，社会経済状態，空調使 用率等の違いによる効果修飾もあり得る。

\section{ま と め}

中国，台湾，韓国など近隣諸国の都市に抢ける研究報 告では黄砂曝露の短期影響として，呼吸器疾患および循 環器疾患による死亡や受診・入院患者数増加が報告され ているが，統計学的に有意な差が見られない文献も多数 
あった。通常の大気污染疫学研究と比較してサンプルサ イズの検討をより慎重に行う必要があるかもしれない。 また，曝露評価や交絡因子の調整が明確に記述されてい ない文献が多く，十分なエビデンスがあるとは言いがた い。さらに，黄砂曝露の長期影響について検討した文献 はなかったが，今後検討すべき課題と言える。わが国に 沶いてもこれらの点を十分考慮した疫学研究が実施され ることが望まれる。

\section{謝辞}

この文献調査は環境省による平成 20 年度「黄砂等大気 污染物質の健康影響に関する基礎調査」で行われたもの の一部である。本論文については筆者らの見解を述べた ものであり，環境省の見解を表したものではない。

\section{文献}

（1）黄砂問題検討会. 黄砂問題検討会報告書. 2005 .

( 2 ) Mori I, Nishikawa M, Tanimura T, Quan H. Change in size distribution and chemical composition of kosa (Asian dust) aerosol during long-range transport. Atmos Environ. 2003; 37:4253-4263.

( 3 ) Ho H-M, Rao CY, Hsu H-H, Chiu Y-H, Liu C-M, Chao HJ. Characteristics and determinants of ambient fungal spores in Hualien, Taiwan. Atmos Environ. 2005;39:5839-5850.

( 4 ) Ichinose T, Yoshida S, Hiyoshi K, Sadakane K, Takano H, Nishikawa M, Mori I, Yanagisawa R, Kawazato H, Yasuda A, Shibamoto T. The effects of microbial materials adhered to Asian sand dust on allergic lung inflammation. Arch Environ Contam Toxicol. 2008;55:348-357.

( 5 ) Meng Z, Lu B. Dust events as a risk factor for daily hospitalization for respiratory and cardiovascular diseases in Minqin, China. Atmos Environ. 2007;41:7048-7058.

( 6 ) Bell ML, Levy JK, Lin Z. The effect of sandstorms and air pollution on cause-specific hospital admissions in Taipei, Taiwan. Occup Environ Med. 2008;65:104-111.

( 7 ) Chan CC, Chuang KJ, Chen WJ, Chang WT, Lee CT, Peng $\mathrm{CM}$. Increasing cardiopulmonary emergency visits by longrange transported Asian dust storms in Taiwan. Environ Res. 2008; 106:393-400.

( 8 ) Chang CC, Lee IM, Tsai SS, Yang CY. Correlation of Asian dust storm events with daily clinic visits for allergic rhinitis in Taipei, Taiwan. J Toxicol Environ Health A. 2006;69:229-235.

( 9 ) Chen YS, Sheen PC, Chen ER, Liu YK, Wu TN, Yang CY. Effects of Asian dust storm events on daily mortality in Taipei, Taiwan. Environ Res. 2004;95:151-155.

(10) Chen YS, Yang CY. Effects of Asian dust storm events on daily hospital admissions for cardiovascular disease in Taipei, Taiwan. J Toxicol Environ Health A. 2005;68: 1457-1464.

(11) Cheng MF, Ho SC, Chiu HF, Wu TN, Chen PS, Yang CY. Consequences of exposure to Asian dust storm events on daily pneumonia hospital admissions in Taipei, Taiwan. $\mathrm{J}$
Toxicol Environ Health A. 2008;71:1295-1299.

(12) Chiu HF, Tiao MM, Ho SC, Kuo HW, Wu TN, Yang CY. Effects of Asian dust storm events on hospital admissions for chronic obstructive pulmonary disease in Taipei, Taiwan. Inhal Toxicol. 2008;20:777-781.

(13) Lai LW, Cheng WL. The impact of air quality on respiratory admissions during Asian dust storm periods. Int $\mathrm{J}$ Environ Health Res. 2008; 18: 429-450.

(14) Yang CY. Effects of Asian dust storm events on daily clinical visits for conjunctivitis in Taipei, Taiwan. J Toxicol Environ Health A. 2006;69:1673-1680.

(15) Yang CY, Chen YS, Chiu HF, Goggins WB. Effects of Asian dust storm events on daily stroke admissions in Taipei, Taiwan. Environ Res. 2005; 99:79-84.

(16) Yang CY, Cheng MH, Chen CC. Effects of Asian dust storm events on hospital admissions for congestive heart failure in Taipei, Taiwan. J Toxicol Environ Health A. 2009; 72:324-328.

(17) Yang CY, Tsai SS, Chang CC, Ho SC. Effects of Asian dust storm events on daily admissions for asthma in Taipei, Taiwan. Inhal Toxicol. 2005; 17:817-821.

(18) Hwang SS, Cho SH, Kwon HJ. Effects of the severe asian dust events on daily mortality during the spring of 2002 , in Seoul, Korea. J Prev Med Public Health. 2005;38:197202

(19) Kwon HJ, Cho SH, Chun Y, Lagarde F, Pershagen G. Effects of the Asian dust events on daily mortality in Seoul, Korea. Environ Res. 2002;90:1-5.

(20) Park JW, Lim YH, Kyung SY, An CH, Lee SP, Jeong SH, $\mathrm{Ju}$ YS. Effects of ambient particulate matter on peak expiratory flow rates and respiratory symptoms of asthmatics during Asian dust periods in Korea. Respirology. 2005;10: 470-476.

(21) Yoo Y, Choung JT, Yu J, Kim do K, Koh YY. Acute effects of Asian dust events on respiratory symptoms and peak expiratory flow in children with mild asthma. J Korean Med Sci. $2008 ; 23: 66-71$.

（22）小沢昌彦，市頭教克，内尾英一. 春季カタルの増悪と 黄砂の観測時期との関連. あたらしい眼科 2008;25： 1281-1284.

(23) Bennett CM, McKendry IG, Kelly S, Denike K, Koch T. Impact of the 1998 Gobi dust event on hospital admissions in the Lower Fraser Valley, British Columbia. Sci Total Environ. 2006;366:918-925.

(24) Husar RB, Tratt DM, Schichtel BA, Falke SR, Li F, Jaffe D, Gassó S, Gill T, Laulainen NS, Lu F, Reheis MC, Chun Y, Westphal D, Holben BN, Gueymard C, McKendry I, Kuring N, Feldman GC, McClain C, Frouin RJ, Merrill J, DuBois D, Vignola F, Murayama T, Nickovic S, Wilson WE, Sassen K, Sugimoto N, Malm WC. Asian dust events of April 1998. J Geophys Res. 2001; 106:18317-18330.

(25) Cheng MT, Lin YC, Chio CP, Wang CF, Kuo CY. Characteristics of aerosols collected in central Taiwan during an Asian dust event in spring 2000. Chemosphere. 2005;61: 1439-1450.

（26）杉本伸夫，清水 厚，松井一郎，鵜野伊津志，荒生公 雄，陳岩．連続運転偏光ライダーネットワークに 
よる黄砂の動態把握. 地球環境 2002; 7: 197-207.

(27) Health Effects Institute. Revised Analyses of Time-Series Studies of Air Pollution and Health. Boston MA: Health Effects Institute, 2003.

(28) Schwartz J, Spix C, Touloumi G, Bacharova L, Barumamdzadeh T, le Tertre A, Piekarksi T, Ponce de Leon A, Ponka A, Rossi G, Saez M, Schouten JP. Methodological issues in studies of air pollution and daily counts of deaths or hospital admissions. J Epidemiol Community
Health. 1996;50 Suppl 1:S3-11.

(29) Zeger SL, Thomas D, Dominici F, Samet JM, Schwartz J, Dockery D, Cohen A. Exposure measurement error in timeseries studies of air pollution: concepts and consequences. Environ Health Perspect. $2000 ; 108$ :419-426.

(30) U.S. Environmental Protection Agency. U.S. EPA. Air Quality Criteria for Particulate Matter. Washington, D.C., 2004.

（31）環境省．黄砂実態解明調査報告書． 2009 ． 